\title{
Methicillin resistant Staphylococcus aureus adhesion to human umbilical vein endothelial cells demonstrates wall shear stress dependent behaviour
}

\author{
Kayla D Viegas ${ }^{1}$, Sharul S Dol', M Mehdi Salek', Robert D Shepherd ${ }^{2}$, Robert M Martinuzzi ${ }^{1}$ and \\ Kristina D Rinker ${ }^{2,3,4,5^{*}}$
}

* Correspondence: tina. rinker@ucalgary.ca

${ }^{2}$ Department of Chemical and Petroleum Engineering, Schulich School of Engineering, University of Calgary, Calgary, AB, Canada Full list of author information is available at the end of the article

\begin{abstract}
Background: Methicillin-resistant Staphylococcus aureus (MRSA) is an increasingly prevalent pathogen capable of causing severe vascular infections. The goal of this work was to investigate the role of shear stress in early adhesion events.

Methods: Human umbilical vein endothelial cells (HUVEC) were exposed to MRSA for 15-60 minutes and shear stresses of 0-1.2 $\mathrm{Pa}$ in a parallel plate flow chamber system. Confocal microscopy stacks were captured and analyzed to assess the number of MRSA. Flow chamber parameters were validated using micro-particle image velocimetry (PIV) and computational fluid dynamics modelling (CFD).

Results: Under static conditions, MRSA adhered to, and were internalized by, more than $80 \%$ of HUVEC at 15 minutes, and almost $100 \%$ of the cells at 1 hour. At 30 minutes, there was no change in the percent HUVEC infected between static and low flow $(0.24 \mathrm{~Pa})$, but a $15 \%$ decrease was seen at $1.2 \mathrm{~Pa}$. The average number of MRSA per HUVEC decreased 22\% between static and $0.24 \mathrm{~Pa}$, and 37\% between $0.24 \mathrm{~Pa}$ and 1.2 Pa. However, when corrected for changes in bacterial concentration near the surface due to flow, bacteria per area was shown to increase at $0.24 \mathrm{~Pa}$ compared to static, with a subsequent decline at 1.2 Pa.

Conclusions: This study demonstrates that MRSA adhesion to endothelial cells is strongly influenced by flow conditions and time, and that MSRA adhere in greater numbers to regions of low shear stress. These areas are common in arterial bifurcations, locations also susceptible to generation of atherosclerosis.
\end{abstract}

\section{Background}

Infections of the cardiovascular system, including those involving prostheses and devices, are a globally recurring problem. Vascular infections are often life-threatening, spread easily, and costly to treat. Furthermore, infection is a common problem affecting the success of biomedical implants, such as vascular stents [1]. Bacteria can be introduced through surgical interventions, travel through the bloodstream and infect the endothelial cells lining the blood vessels. Cardiovascular disease has also been linked to microbial infection [2,3], with attachment of bacterial pathogens to endothelium or extracellular matrix being an initial step in the process [4].

(c) 2011 Viegas et al; licensee BioMed Central Ltd. This is an Open Access article distributed under the terms of the Creative Commons Attribution License (http://creativecommons.org/licenses/by/2.0), which permits unrestricted use, distribution, and reproduction in any medium, provided the original work is properly cited. 
Staphylococcus aureus is a highly adaptable microbial pathogen that is considered to be a leading cause of various community- and hospital-acquired infections [5]. The frequency of $S$. aureus infection has risen dramatically over the last few decades in accordance with the number of patients receiving vascular implants, such that $S$. aureus accounts for the majority of device-related infections [6]. In addition, S. aureus is the primary cause of endovascular and endocardial infections that are extremely difficult to treat, with mortality rates between 40 and $50 \%$ at one year [7]. Of particular concern is the ability of $S$. aureus to become tolerant to antibiotic therapies, and to generate antibiotic resistant strains.

One such strain is Methicillin resistant Staphylococcus aureus (MRSA). In addition to its intrinsic resistance to methicillin, MRSA is also insensitive to other common antibiotics such as oxacillin, penicillin and amoxicillin [8]. MRSA was first identified in 1961 and is now the most common antibiotic-resistant bacteria worldwide [8]. MRSA infection rates have continued to grow in recent decades: in 1974, $2 \%$ of S. aureus infections in US intensive-care units were caused by MRSA, in 1995 this number was $22 \%$, and in 2003, 64\% [9]. Approximately 94,000 Americans suffer each year from invasive MRSA infections, and an estimated 19,000 of these incidences (20\%) result in death [10]. Globally, MRSA is known to be associated with longer hospital stays, increased mortality, morbidity and much higher costs of treatment.

The location, strength, and magnitude of vascular bacterial adhesion, along with subsequent cellular interactions involved in disease progression, are likely to be highly dependent on the hydrodynamic environments experienced within affected vessels. Once in the bloodstream, bacteria contact the vascular endothelium. Endothelial cells mediate many vascular functions including inflammatory responses and transendothelial migration of nutrients, biological molecules, and leukocytes into the surrounding tissue [11]. These functions occur under the dynamic conditions of blood flow, and are strongly affected by hemodynamic forces. Shear stress levels $\geq 1 \mathrm{~Pa}$, which generally occur through straight portions of the arteries, typically correspond to healthy, disease resistant regions of the vasculature, while low shear stress $(\leq 0.4 \mathrm{~Pa})$, which is found at arterial branch points and areas of curvature, often corresponds to areas susceptible to both atherosclerosis and microbial adhesion [12-14]. Receptor-ligand adhesive bonds are strongly affected by flow conditions. While it would seem from intuition and theory that receptor-ligand bonds should form less frequently and break more quickly under flow, experimental evidence has shown that in some cases the opposite occurs. We previously showed monocyte adhesion to HUVEC to be shear stress dependent, with stronger adhesion occurring with increased shear stress [15], possibly due to increased cell or microvilli deformation [16]. However, the bonds themselves may respond differently depending on the level of force (from shear stress, atomic force microscopy, or other methods). Adhesive bonds are characterized as 'slip' bonds if bond lifetimes decrease under increased force and catch bonds if the opposite occurs. While many studies have focused on P- and L-selectins involved in leukocyte adhesion [17,18], a catch bond has been identified in Escherichia coli $[19,20]$. Therefore it is essential to observe adhesive interactions under physiologically relevant conditions. This may enable establishment of more accurate models of vascular infection in the human body and evaluation of 
specific adhesion mechanisms. A few studies have investigated $S$. aureus adhesion to endothelium under flow [21-23], however none of these involve MRSA.

In vitro systems have been developed that allow cultured endothelial cells to be exposed to well-defined flow conditions, and include orbital shakers [24], cone and plate viscometers [25,26], and parallel-plate flow chambers (PPFC) [15,16,27-31]. PPFC enable establishment of fully developed laminar flow within the channel of the chamber and theoretically should allow exposure of cells to uniform flow fields. However, many PPFCs have been found to not provide uniform shear stresses across the surface of the chamber [32-34]. Therefore, cell responses may not be consistent over the chamber area [34].

This study investigated the hypothesis that shear stress inhibits MRSA adhesion and subsequent infection of vascular endothelium. The objectives of this study were to first evaluate the performance of a newly designed PPFC for its ability to provide defined flow and uniform shear stress to cultured cells, and second, to use this PPFC to analyze the influence of shear stress on MRSA infection of endothelium. Human umbilical vein endothelial cells (HUVEC), were selected since they represent a good endothelial model and are widely used in the field [15,16,31]. Further, since many S. aureus experiments have been performed with HUVEC or the HUVEC cell line EA hy926, this enables closer comparisons with previous data [22,23,35-37].

\section{Methods}

\section{Bacterial culture}

The bacterial strain used for all experiments, MRSA UC18, a hospital-acquired isolate, was kindly provided by Dr. Howard Ceri (University of Calgary). MRSA was routinely cultured in Tryptic Soy Broth (TSB) at $37^{\circ} \mathrm{C}$ and $100 \mathrm{rpm}$. Bacterial growth was quantified using optical density (OD) at a spectrophotometer light wavelength of $600 \mathrm{~nm}$ and viable plate counts. Cells passaged from actively growing cultures were maintained at $37^{\circ} \mathrm{C}$ under constant rotation, and harvested at an OD of 0.50 , after $\sim 3 \mathrm{~h}$ of incubation. As determined by growth curves, this point corresponded to mid-exponential phase. All bacterial ODs were correlated to colony counts (measured in colony forming units; CFU). Prior to adhesion studies, bacteria were labelled for 30 minutes at $37^{\circ} \mathrm{C}$ with a 1:1000 dilution of SYTO 9 (Invitrogen, Grand Island, NY, USA) in Dulbecco's Modified Eagle's Medium (DMEM, Sigma-Aldrich, St. Louis, MO, USA) supplemented with $2 \%$ Fetal Bovine Serum (FBS). After labelling, cells were washed twice with TBS and diluted in DMEM to a concentration of $10^{7} \mathrm{CFU} / \mathrm{mL}$.

\section{Endothelial cell culture}

Pooled Human Umbilical Vein Endothelial Cells (HUVEC; Lonza, Walkersville, MD, USA) were cultured from supplied stock and expanded up to a maximum of passage 6 . Tissue culture flasks and glass slides were coated with $0.1 \%$ gelatin (Difco, Becton, Dickinson, Sparks, MD, USA) in M199 (Sigma-Aldrich) prior to cell seeding. Slides were usually confluent and ready for use after 2 days.

\section{In vitro flow model}

The PPFC system and methods used for this study were similar to that used by Shepherd et al., 2009 [30]. As shown in Figure 1A, the flow chamber was comprised of 


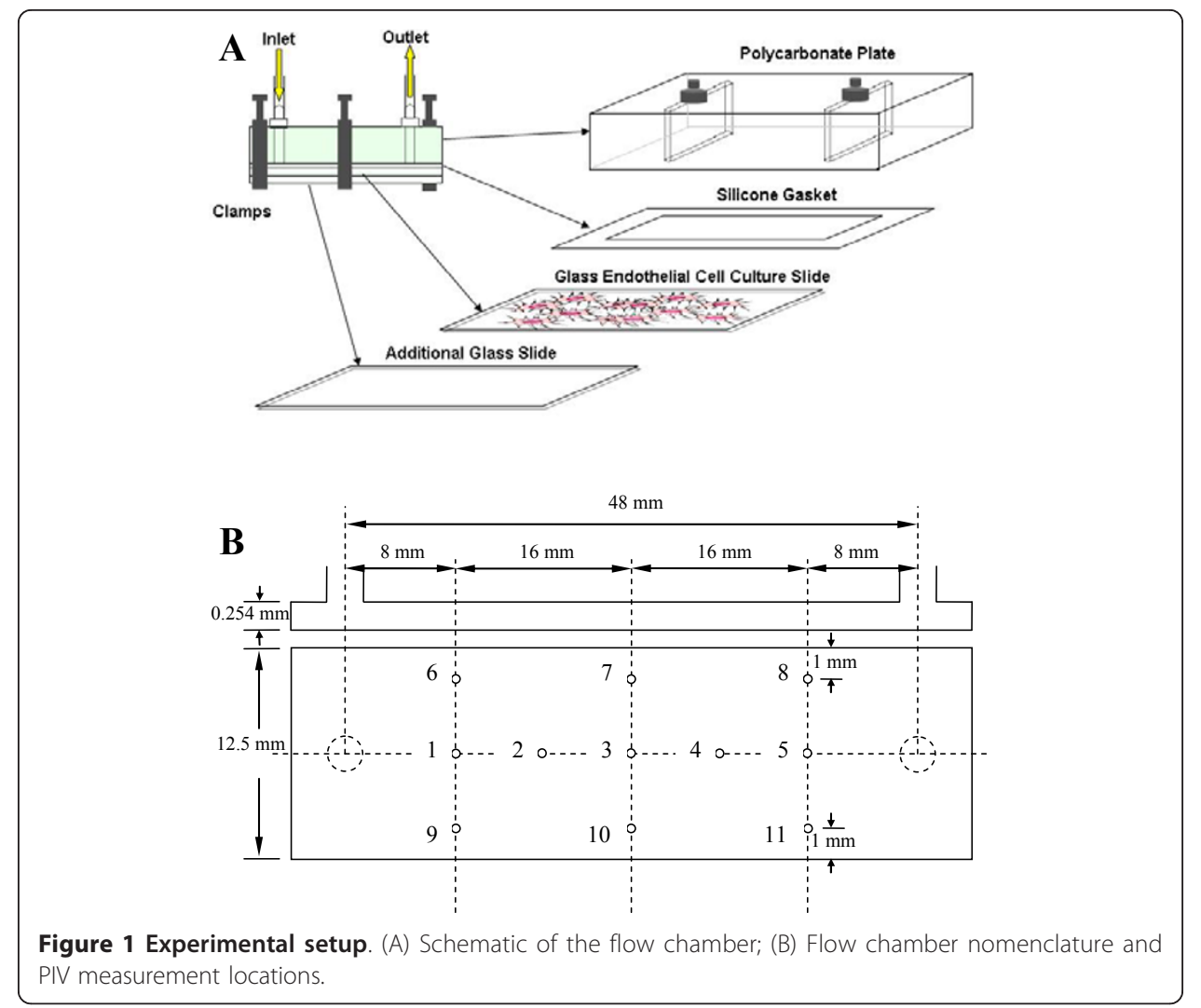

a polycarbonate top plate with ports for an inlet and outlet, a $254 \mu \mathrm{m}$ thick silicon rubber gasket (Specialty Manufacturing, Saginaw, MI, USA) with a removed rectangular section in the center to form the flow channel (clear section: $w=1.25 \mathrm{~cm}, l=4.6$ $\mathrm{cm}$ ) and a glass microscope slide with a confluent monolayer of HUVEC. DMEM containing labelled MRSA was pumped using a variable speed peristaltic pump (MasterFlex ${ }^{\circledR} \mathrm{L} / \mathrm{S}^{\circledR}$; Cole Parmer, Montreal, QC, Canada) through MasterFlex 16 Norprene Tubing from a media bottle, through a pulse dampener (Cole Parmer), to the flow chamber, and back into the media bottle. A heat lamp was used to maintain the temperature of the flow circuit at approximately $37^{\circ} \mathrm{C}$. At the end of the experiments, slides were washed twice with HEPES Buffered Saline Solution (HBSS), fixed with $4 \%$ paraformaldehyde for $20 \mathrm{~min}$, rinsed twice with PBS and mounted with VECTASHIELD ${ }^{\circledR}$ Mounting Medium (Vector Labs, Burlington, ON, Canada) and a cover slip. The nominal average wall shear stress, $\tau_{\mathrm{w}}$, for flow in the channel was determined by:

$$
\tau_{w}=\frac{6 Q \mu}{w h^{2}}
$$

where $Q$ is the volumetric flow rate $\left(2 \mathrm{ml} \mathrm{min}^{-1}\right.$ or $\left.10 \mathrm{ml} \mathrm{min}^{-1}\right), \mu$ is the fluid viscosity, $w$ is the channel width $(12.5 \mathrm{~mm})$, and $h$ is the flow path height. For this chamber, the width to height ratio was 49 . For a Newtonian fluid, shear rate, $\dot{\gamma}$, is related to shear stress according to:

$$
\dot{\gamma}=\frac{\tau_{w}}{\mu}
$$


For each flow condition investigated, the Reynolds number was calculated in order to verify that flow within the channel was laminar. The following formula was used:

$$
\begin{aligned}
& \operatorname{Re}=\frac{Q D_{h}}{v A} \\
& \text { where } \\
& D_{h}=2 h \\
& v=\mu / \rho \\
& A=w h
\end{aligned}
$$

According to the PIV analysis (see below), the height of the HUVEC and extracellular matrix layer was $20.1 \pm 3.9 \mu \mathrm{m}$ [38]. This height was subtracted from the channel height $(254 \mu \mathrm{m})$ to determine the height of the flow path, $\mathrm{h}$. The density and viscosity of the culture media were $0.9852 \mathrm{~g} \cdot \mathrm{cm}^{-3}$ and $0.831 \mathrm{cP}$ (determined using a capillary viscometer (Cannon-Fenske; Cannon Instrument Company State College, PA, USA), respectively. These values yield shear stresses of $0.24 \mathrm{~Pa}$ and $1.2 \mathrm{~Pa}$ (at shear rates of $293 \mathrm{~s}^{-1}$ and $1460 \mathrm{~s}^{-1}$ and Reynolds numbers of 6.57 and 32.9 , respectively) for the conditions used in the infection study. The Reynolds numbers less than 1200 indicate that flow is in the laminar regime. Physiological values of Reynolds numbers (200-6000) could not be reproduced due to the high flow rates needed [39].

The infection data was normalized to separate adhesion kinetics from transport effects by the method of Munn et al. [15,40,41]. The settling velocity was calculated as:

$$
V_{s}=\frac{2\left(\rho_{c}-\rho\right) g r^{2}}{9 \mu}
$$

where $\rho$ is the density of the fluid, $\rho_{\mathrm{c}}$ is the density of the bacterium $\left(1.45 \mathrm{~g} \mathrm{~cm}^{-3}\right.$ [42]), $\mathrm{g}$ is gravitational force, $\mathrm{r}$ is the radius of the bacterium $(0.5 \mu \mathrm{m})$ and $\mu$ is the viscosity of the medium. The dimensionless concentration in the steady state region of the flow chamber is determined as follows:

$$
\frac{\psi}{C}=1+\frac{V_{s} x}{u h^{\prime}}
$$

where $\psi$ is the steady state concentration near the surface, $C$ is the concentration of bacteria in the bulk fluid $\left(1 \times 10^{7}\right.$ cells mll $\left.{ }^{-1}\right), x$ is the distance from the inlet (2.3 $\mathrm{cm}), u$ is the velocity and $h^{\prime}$ is the height of fluid (taken to be one cell diameter, 1 $\mu \mathrm{m}[41,43])$. The velocity, $u$, was determined using the method of Goldman et al. [44] to take into account the lower velocity of a neutrally buoyant sphere near the wall. The dimensionless concentration was normalized against the value determined for the static condition then multiplied by the experimentally determined values as in previous work [15].

The forces acting on a bacterium attached to an endothelial cell were determined using the method discussed in Rinker et al. [15]. The drag force, $F_{x}$, is given by

$$
F_{x}=F_{x}^{*} 6 \pi r^{2} \tau
$$

where $r$ is the cell diameter $(1 \mu \mathrm{m})$ and $\mathrm{t}$ is the shear stress. $F_{x}{ }^{*}$ is equal to 1.7005 for the case where the bacterium is touching the surface [44]. 


\section{Imaging}

An Olympus Fluoview FV1000 Confocal Scanning Laser Microscope (CSLM) was used to take fluorescent image stacks using a water-immersed, coverslip-corrected $60 \times$ objective and an Argon laser. For each condition, a minimum of three replicates were analyzed. For each experiment, between 4 and 12 confocal stacks (thickness of slice = $0.5 \mu \mathrm{m}$ ) were taken randomly along the flow channel. This generated data encompassing adhesion to a minimum of 100 HUVEC per experiment. Within each image stack taken, all fully visible HUVEC were analyzed, with any cell only partially contained in the field of view excluded. All HUVEC with one or more adherent MRSA were considered infected. The number of HUVEC associated MRSA were counted on a per-cell basis. The area analyzed in each picture was $0.001 \mathrm{~cm}^{-2}$.

\section{PIV measurements}

Flow field information was obtained for the parallel plate flow chamber with a microPIV system (TSI) as previously reported [38]. Figure 1B shows the measurement locations inside the chamber. Duke red fluorescent particles $(2.0 \mu \mathrm{m}$ nominal diameter $)$ were used as tracers (concentration of $0.3 \%$ by volume). The particles were illuminated with a $532 \mathrm{~nm}$ Nd:YAG laser. A Nikon Plan Fluor 10X 0.3 NA objective lens was used with an inverted Nikon microscope. The images were captured by a CCD camera (POWERVIEW 4M; $2048 \times 2048$ pixels) with a $2 \times$ projection lens giving an effective view field of $760 \mu \mathrm{m} \times 760 \mu \mathrm{m}$. A volume illumination technique was used to define the PIV measurement plane [45]. The velocity field was estimated from ensemble averages of 100 image pairs acquired at a rate of $7.5 \mathrm{~Hz}$ with an inter-image time delay of $300 \mu \mathrm{s}$ to $500 \mu \mathrm{s}$. TSI Insight ${ }^{\circledR}$ software was used to analyze the captured images using a cross-correlation technique with a Gaussian window function. The spatial resolution, based on $64 \times 64$ pixel interrogation spots, was $11.84 \mu \mathrm{m} / \mathrm{spot}$. A standard $50 \%$ interrogation area overlap was used to represent the vector field. The local shear stress was estimated from the velocity gradient at the wall:

$$
\tau_{\mathrm{w}}=\left.\mu \frac{\mathrm{du}}{\mathrm{dz}}\right|_{\text {wall }}
$$

The velocity gradient was estimated using a three-point fit. The overall measurement uncertainty is estimated to be $\pm 2 \%$ and $\pm 6 \%$ for the local velocity and wall shear stress, respectively, based on pixel resolution and repeatability.

The uncertainty in the location is related to the PIV measurement depth, $\delta z$, which is related to the depth of focus of the recording lens and can be estimated by considering the effects of: diffraction, geometric optics and the finite size of the particle [45]:

$$
\delta z=\frac{3 n \lambda_{0}}{N A^{2}}+\frac{2.16 d_{p}}{\tan \theta}+d_{p}
$$

where $\mathrm{n}$ is the refractive index of the fluid between the micro-fluidic device and the objective lens; $\lambda_{0}$ is the wavelength of light, in vacuum, imaged by the optical system; $N A$ is the numerical aperture of the objective lens; $\theta$ is the light collection angle and $d_{p}$ is the particle diameter. The resulting measurement depth uncertainty is about $20 \mu \mathrm{m}$. 


\section{CFD modeling}

FLUENT version 6.3.2 was used to model the flow through the PPFC in the absence (clean chamber) or presence of cells using grids generated in Gambit. The steady three-dimensional forms of the continuity and Navier-Stokes equations were solved with constant media properties at $20^{\circ} \mathrm{C}$. For the clean flow chamber case, a structured, rectangular grid was used. For the case with endothelial cells, the endothelial cell surfaces were reconstructed in Gambit using elevations measured from micro-PIV at 225 points in a plane of $700 \mu \mathrm{m} \times 700 \mu \mathrm{m}$. The velocity profile was measured using microPIV at each of these 225 points to locate the surface (according to no slip boundary condition at the solid surfaces). Interpolation was used to construct the surface based on these 225 points. In this method the interpolated surface was constrained to pass through all measured vertices with zero tolerance, while minimizing the curvature. Hexagonal grids with low skewness $(<0.4)$ were generated in the domain. Computational grids for the endothelial cells surfaces and two perpendicular planes are shown in Figure 2. A grid sensitivity analysis was conducted for different node-density grids to select the optimum grid (the optimum grid included 98000 computational cells in this study). A double-precision solver was used which is more accurate for the geometries with very disparate length scales. The momentum equations were solved with first order upwind schemes and the SIMPLE algorithm was used for the pressure velocity coupling.

For the PPFC without cells, a uniform velocity profile was used at the inlet and a no slip boundary condition was applied at the walls. Outflow boundary condition was used at the outlet: the flow variable gradients normal to the boundary are set to zero. For the PPFC with endothelial cells, the inlet velocity profile measured experimentally was used at the beginning of the solution domain. No slip boundary conditions were applied at the lateral walls and endothelial cell surfaces. Additional details of the CFD analysis are provided in Dol et al. [38].

\section{Statistical analysis}

Data is reported as the mean +/- the standard error of the mean (SEM). Systat (v. 13, Systat Software Inc, Chicago, IL) was used to perform analysis of variance (ANOVA).

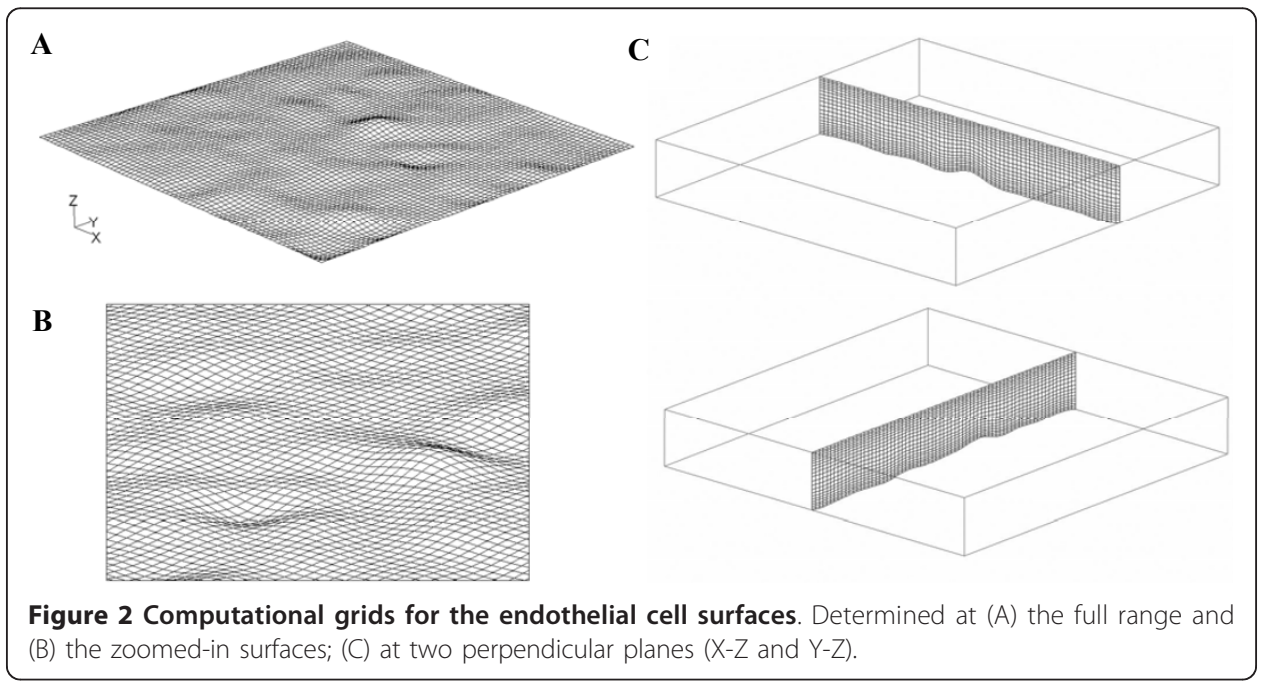


A Tukey post-test analysis was performed on data pairs. P-values $<0.05$ (corresponding to a $95 \%$ confidence interval) were considered statistically significant.

\section{Results}

MRSA adhered to HUVEC and was internalized

In order to assess binding of MRSA to endothelium, experiments were first performed under static conditions to develop a method to quantify infection and to determine time dependence. HUVEC were exposed to MRSA collected during exponential growth, during which bacteria have a higher capacity to adhere to and infect host cells [46-48]. After 30 minutes of adhesion under static conditions, MRSA were seen in multiple slices of the image stack (Figure 3). MRSA were found on the surface and in the cytoplasm of the HUVEC. The distribution of bacteria deviated greatly from cell to cell with some endothelial cells having none to very few bound bacteria, with others having many bound bacterial cells. At time points of 15, 30, and 60 minutes, the maximum number of MRSA attached to or inside a single HUVEC were observed to be 31, 68, and 75 respectively (data not shown). MRSA UC18 is a virulent S. aureus strain. 85\% of the exposed HUVEC were infected after 15 minutes and $98 \%$ after 60 minutes; an increase of $15 \%(\mathrm{p}<0.001$; Figure 4A). The average number of MRSA per endothelial cell increased $122 \%$ between time points of 15 and 30 minutes $(p<0.001$;

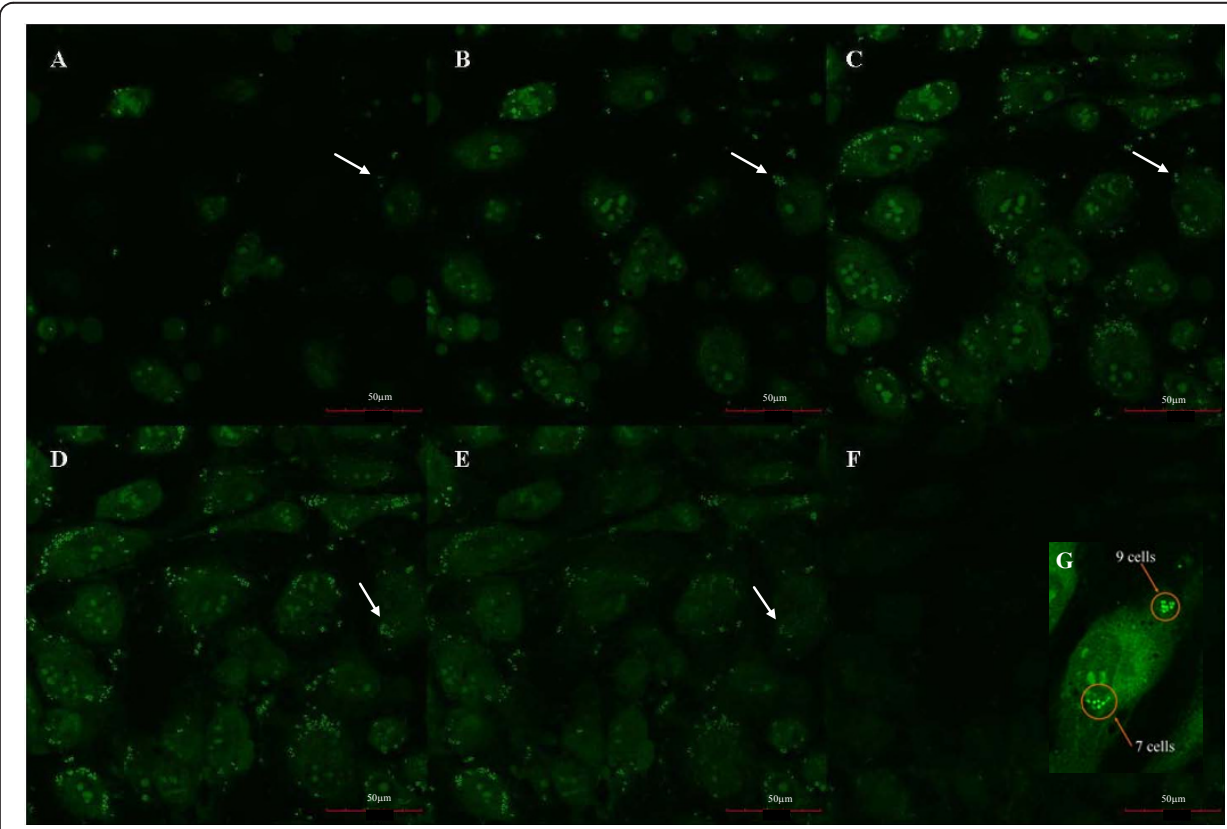

Figure 3 MRSA adhesion and infection of endothelial cells. Selected confocal image slices $(0.5 \mu \mathrm{m}$ thick) from one stack (from (A) the top of the cells through to (F) the bottom of the cells) were taken of HUVEC infected with MRSA under static conditions for 30 minutes. The brighter green dots are adherent MRSA UC18 cells. The arrows point to the same cell in each slice. In (A) only 2 MRSA can be seen at this location, whereas there is a cluster of 7 at the same location in the next slice (B). Two MRSA are seen at the same location in (C). Intracellular MRSA are more easily seen for this cell in (D). The inset in (F) shows a magnification of one cell and identification of bacteria (G). Since there is more than one adherent MRSA, this cell would be considered to be infected. If only this slice was used to analyze this particular endothelial cell, 16 MRSA would be used to determine the average number of MRSA per HUVEC. However, the entire stack was analyzed as cells may be bound in different planes along the height of the cell. 

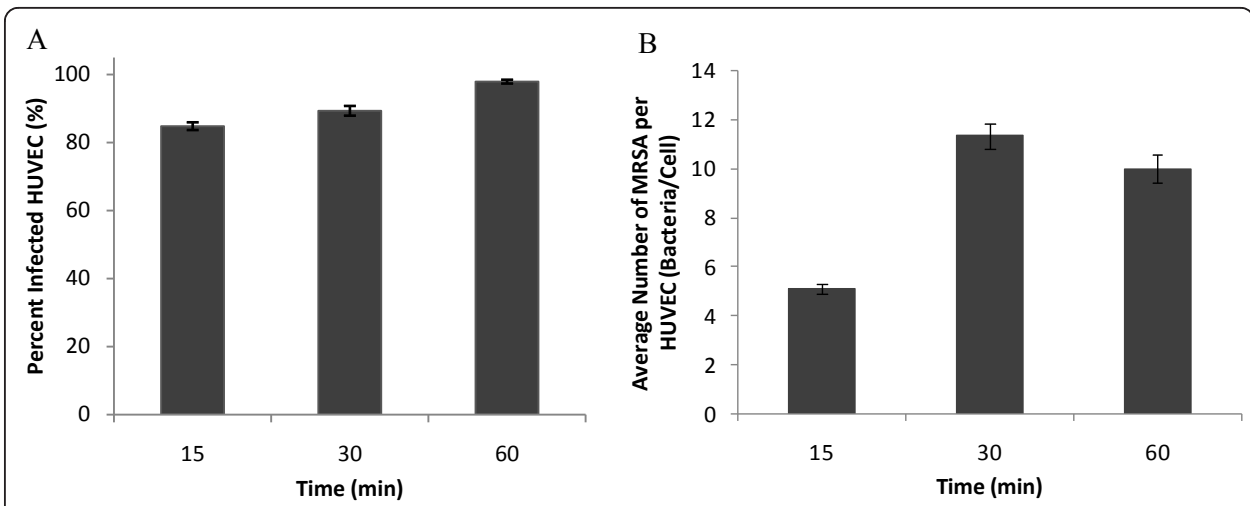

Figure 4 MRSA infection of HUVEC under static conditions. (A) Percentage of infected HUVEC and (B) number of MRSA per HUVEC versus time. HUVEC were exposed to SYTO-9 labelled MRSA for 15, 30, or 60 minutes then analyzed by confocal microscopy to quantify the number of MRSA per HUVEC cell as described in Figure 2. Number of samples analyzed: 15 min: 3 experiments, 556 HUVEC, 2790 MRSA; 30 min: 3 experiments, 411 HUVEC, 4495 MRSA; 60 min: 3 experiments: 423 HUVEC, 4078 MRSA. Error bars are plotted as standard error of the mean (SEM).

Figure 4B). However, from 30 minutes to 60 minutes, this number did not change statistically.

\section{Flow chamber provided uniform flow field}

Next, we wanted to assess the role of fluid shear stress on MRSA adhesion. A parallel plate flow chamber was designed, fabricated and tested. This device was found to provide uniform flow over $95 \%$ of the flow surface, with flow field variation only observed in the vicinity of the lateral walls. A representative cross-section is shown in Figure 5A. All 11 measurement points met target shear stress levels indicating that the influence of the inlet and outlet ports on the flow in the test section was not significant. Characteristic laminar parabolic velocity profiles were observed at locations along the centreline and near the lateral walls (Figures 5B and 5C). Fluid shear stress in the chamber determined by PIV agreed with CFD results within experimental uncertainty for two target shear stress levels $(0.200 \pm 0.006 \mathrm{~Pa}$ and $1.00 \pm 0.06 \mathrm{~Pa})$.

\section{Endothelial cells increased shear variations}

Further testing of the flow chamber was performed with PIV and CFD to determine the effect of the layer of endothelial cells on fluid shear stress levels. Changes in the channel surface topography due to the presence of the endothelial cells induced local variations in the velocity profiles (Figure 6) and, consequently, the surface shear stress experienced by the cells. In the peak regions, the near surface flow speeds were larger than in the trough regions, resulting in a higher shear at the peaks than in the troughs (Figure 7A). The spatial variations in the surface shear stress distribution can be attributed directly to local changes in the cell-matrix thickness (Figure 7B). It was found that the no-slip condition remained valid and that the predicted and measured local surface shear stresses agreed within experimental uncertainty.

\section{Effect of shear stress on MRSA infection of HUVEC}

The characterized PPFC was then used to evaluate adhesion of MRSA to HUVEC under flow. A 30 minute exposure time was selected since this time point yielded 


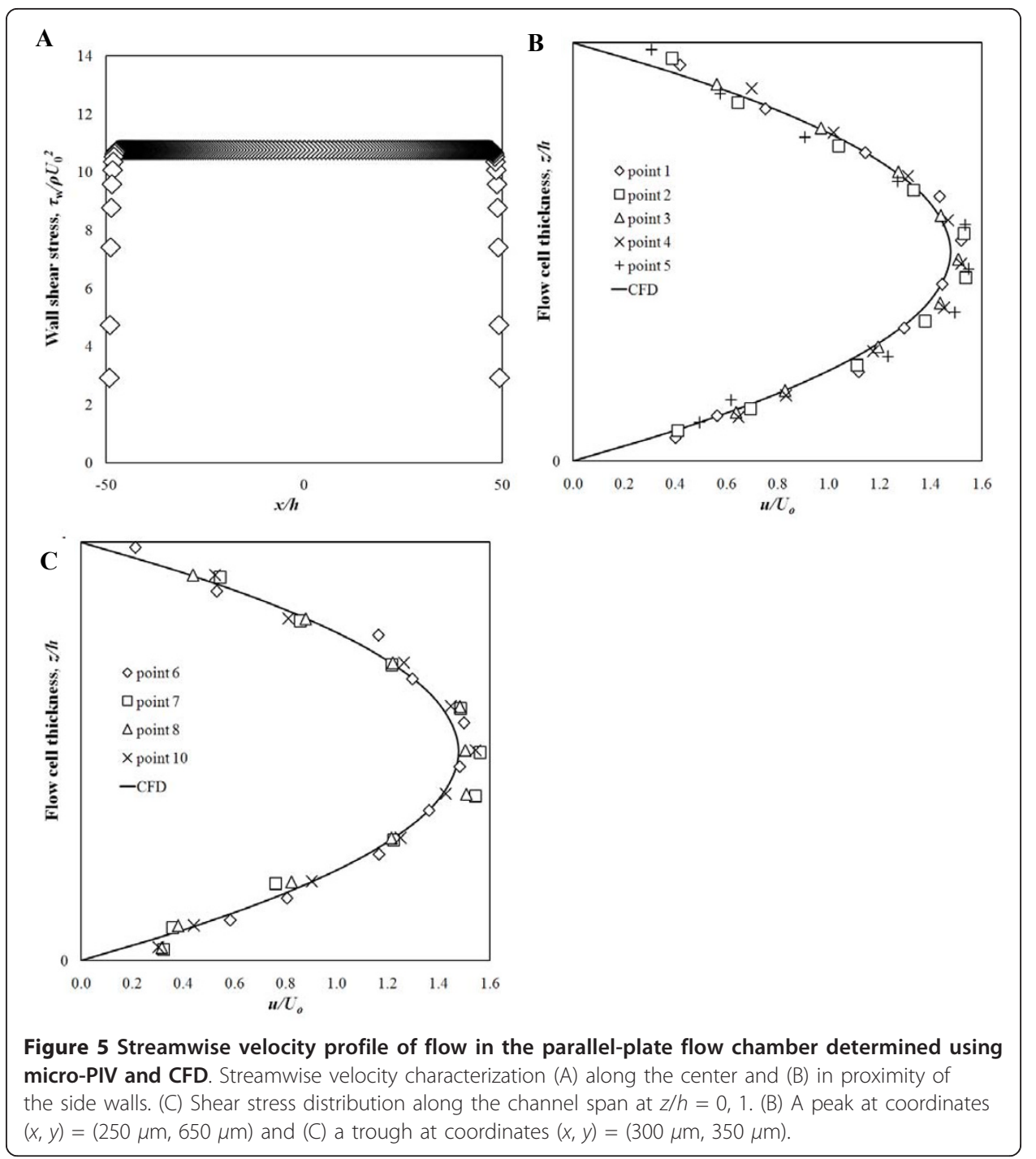

significant adhesion under static conditions, but was short enough that major physiological changes for endothelium and MRSA were less likely to be occurring. Further (as discussed previously), there was no significant increase in adhesion after this point in static studies. When HUVEC were exposed to MRSA in flowing media, the percentage of infected HUVEC decreased 9.3\% between 0.24 Pa and 1.2 Pa ( $\mathrm{p}<0.001$; Figure 8A). However no significant difference was found between static and $0.24 \mathrm{~Pa}$. The average number of MRSA per HUVEC was found to decrease with increasing shear stress (Figure $8 \mathrm{~B}$ ) with a $22 \%$ decrease from static to $0.24 \mathrm{~Pa}(\mathrm{p}<0.001)$ and a further $37 \%$ decrease between $0.24 \mathrm{~Pa}$ and $1.2 \mathrm{~Pa}(\mathrm{p}<0.001)$. The drag force on the attached bacterium was calculated for each flow condition. Adherent MRSA were exposed to a maximum drag force of $1.92 \mathrm{pN}$ at $0.24 \mathrm{~Pa}$ and $9.61 \mathrm{pN}$ at $1.2 \mathrm{~Pa}$.

MRSA infection under flow varied with time

Additional experiments were performed to determine if MRSA adhesion and internalization under flow followed the same trend with time as the experiments performed under static conditions. A low shear stress case (shear stress $0.24 \mathrm{~Pa}$; shear rate 
$293 \mathrm{~s}^{-1}$ ) was selected to determine if saturation of adhesion sites was occurring in adhesion of MRSA to endothelium. MRSA adhered to HUVEC from the start of incubation through 60 minutes, at which time a clear difference was seen between static and dynamic MRSA adhesion and internalization (Figure 9). Analysis of the confocal stacks revealed the majority of MRSA appeared to be distributed along the periphery of the endothelial cells, with few cells attached to the region above the nucleus under flow. For the static condition, it was difficult to find bacteria at the 15 minute time point. However, bacteria are readily seen at 30 and 60 minutes. Under flow, there is a dramatic increase in the number of bacteria between 30 and 60 minutes. As shown in Figure 10A, the percent of HUVEC infected by MRSA under flow was $12 \%$ lower at $0.24 \mathrm{~Pa}$ compared to static conditions after 15 minutes of infection $(74.4 \%$ vs $84.8 \%$; $\mathrm{p}$ < 0.03). At $0.24 \mathrm{~Pa}$, the percent of infected HUVEC increased 20\% between 15 and 30 minutes $(\mathrm{p}<0.001)$ with no significant change between 30 and 60 minutes (Figure 10A). There was no significant change in the number of MRSA per HUVEC between 15 and 30 minutes; however, between 30 minutes and 60 minutes there was a 260\% increase in the number of bacteria $(\mathrm{p}<0.001$; Figure 10B). This was a dramatic increase; a trend which differed from the time course results found under static conditions.

In order to correct for differences in bacterial concentration near the endothelial surface with increasing shear stress, the dimensionless cell concentration was determined and used to normalize the data. The number of bacteria per area was determined for each condition. This data had similar trends to the number of MRSA per HUVEC data already presented. When the experimentally determined bacteria per area was corrected for the dimensionless cell concentration near the surface, there was an increase in MRSA per area from static conditions to a shear rate of $293 \mathrm{~s}^{-1}(0.24 \mathrm{~Pa})$ and a decrease in MRSA per area at $1460 \mathrm{~s}^{-1}(1.2 \mathrm{~Pa})$ at the time point of 30 minutes (Figure 10C).
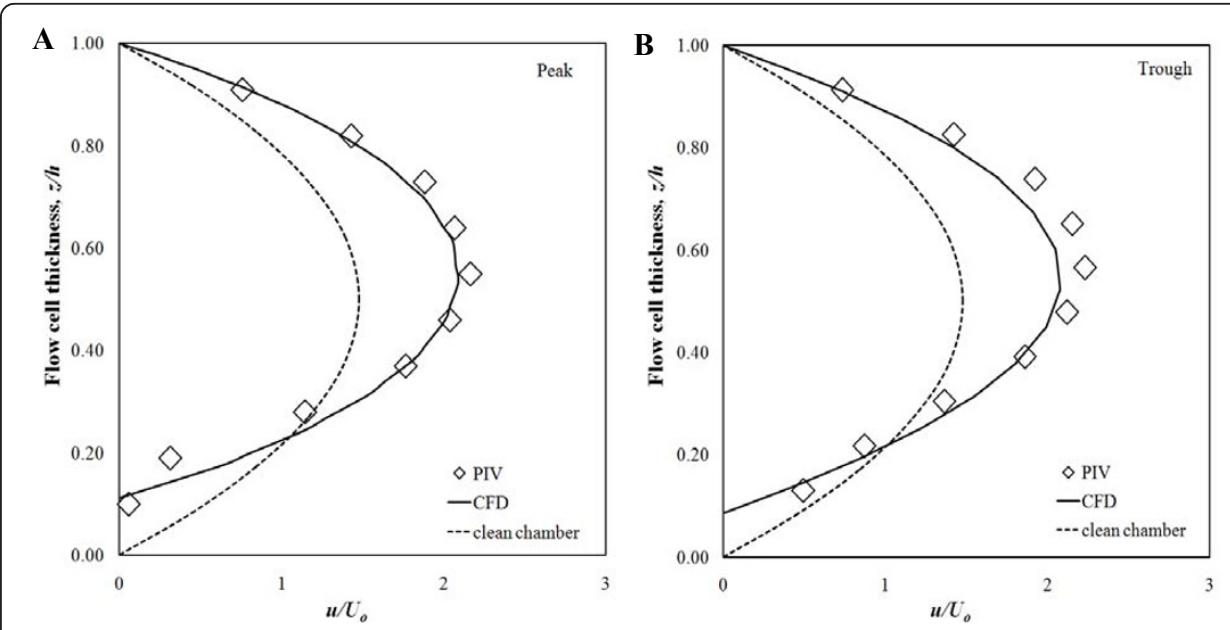

Figure 6 Local distortion of the streamwise velocity profile due to endothelial cell topography. Velocity profiles were determined at point 6 from Figure $1 B$; (A) peak $(x, y)=(250 \mu \mathrm{m}, 650 \mu \mathrm{m})$; (B) trough $(x, y)=(300 \mu \mathrm{m}, 350 \mu \mathrm{m})$. 


\section{Height $(\mu \mathrm{m})$}

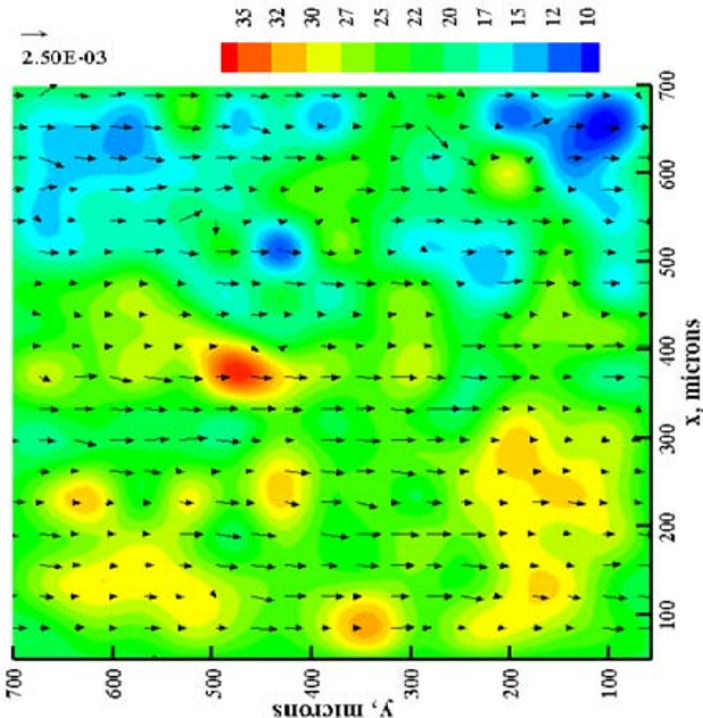

$\oplus$

Wall Shear Stress (Pa)

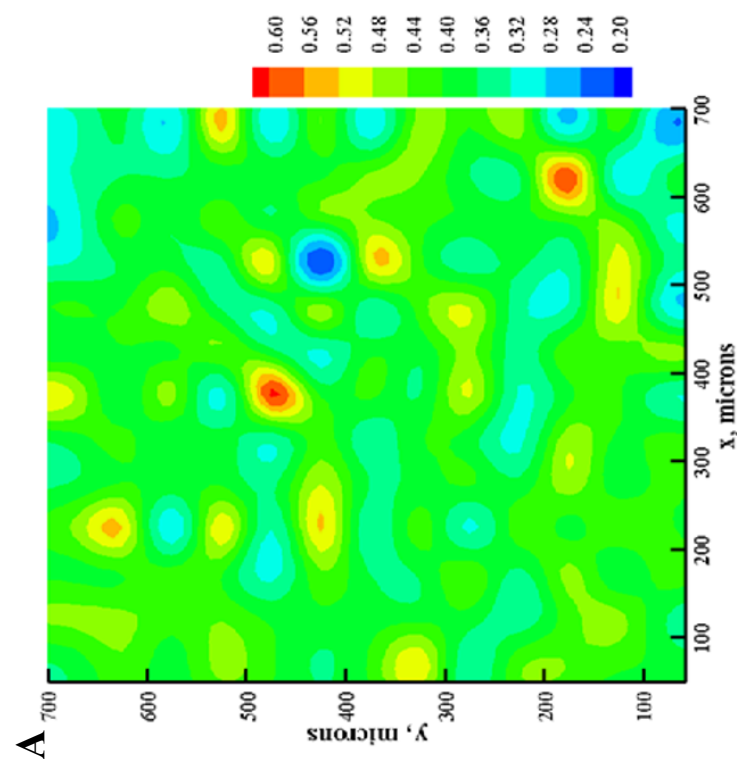

Figure 7 Flow field and surface height changes due to presence of endothelial cells. Velocity field and topography at point 6. (A) Contour of wall shear stress (unit is in Pa) over the endothelial cells as obtained by CFD; (B) PIV velocity field over the contour of cell elevation (unit is in microns).

\section{Discussion}

This study demonstrated that MRSA adheres to human endothelial cells in a manner dependent on fluid flow. The highest adhesion was found at the low shear stress condition $(0.24 \mathrm{~Pa})$, which is a level found in arterial bifurcations. As fluid forces increased to levels seen in straight portions of arterial vessels, normalized MRSA adhesion decreased. Results also showed the capabilities of micro-PIV and CFD in determining the flow field over endothelial cells and the wall shear stress distribution over irregular cell surfaces. 


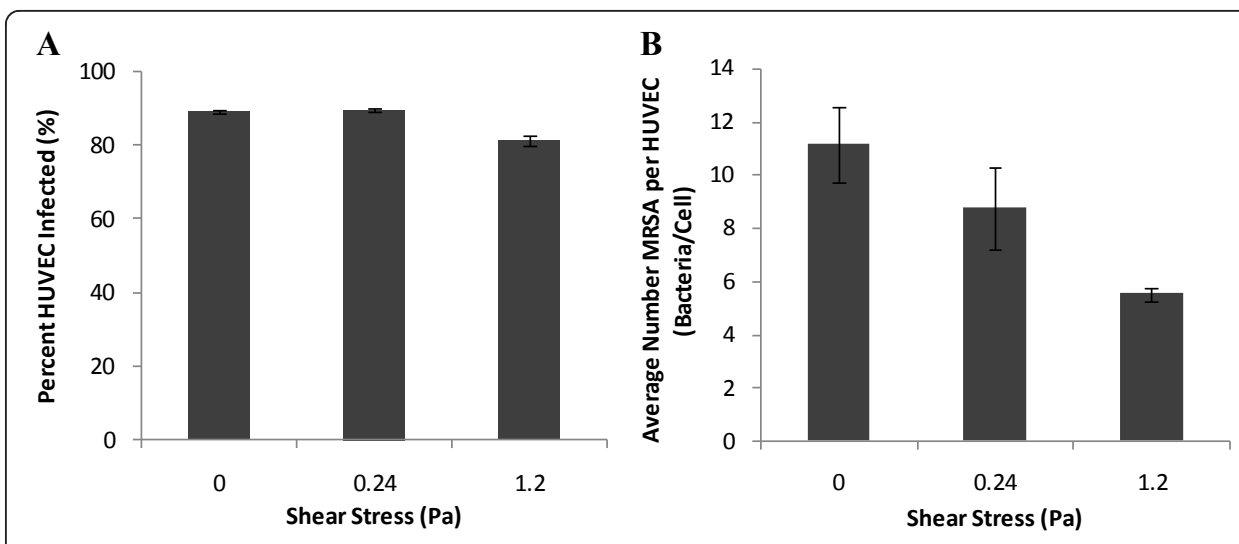

Figure 8 Shear stress dependence of MRSA infection of HUVEC. (A) Percentage of infected HUVEC and (B) number of MRSA per HUVEC versus magnitude of shear stress exposure during infection for 30 minutes. Number of samples analyzed: Static: 3 experiments, 411 HUVEC, 4495 MRSA; 0.24 Pa: 4 experiments, 462 HUVEC, 3795 MRSA; 1.2 Pa: 4 experiments: 546 HUVEC, 3000 MRSA. Error bars are plotted as standard error of the mean (SEM). All conditions in part (B) are significant to a level of $p<0.001$. In part (A), the percent infected HUVEC at 1.2 Pa was significantly different than that at $0.24 \mathrm{~Pa}$ or static conditions to a level of $p$ $<0.001$.

Through analysis of image stacks obtained from confocal microscopy, MRSA infection of HUVEC was found to be heterogeneous (with some HUVEC experiencing a high degree of infection compared to others) and localized. Internalized bacteria were found as early as 15 minutes. For all conditions, most of the adherent bacteria were found around the periphery of the HUVEC. Becker et al. [49] made the same observation and hypothesized that this could be attributed to the fact that these pericellular regions are rich in fibronectin. Based upon our numerical simulations, PIV results and adhesion assays, we predict that there are also micro-scale shear stress effects at play during adhesion under fluid flow. The shear stress over the surface of each endothelial cell reaches a minimum in the junctional areas and a maximum above the cell nucleus. This leads to fluid velocity variations near the monolayer surface that impact cell trajectories. These factors may explain why we observed an increase in MRSA adherence in the area between adjacent cells.

Before normalization, our results showed that the number of MRSA per HUVEC decreased after 30 minutes of steady flow at $293 \mathrm{~s}^{-1}(0.24 \mathrm{~Pa})$ as compared to behaviour under static conditions, and decreased further with increasing shear rate and stress $\left(1.2 \mathrm{~Pa} ; 1460 \mathrm{~s}^{-1}\right)$. These results are similar to those of Shenkman et al. [23] who found a 2.5 fold decrease in S. aureus 8325-4 adhesion to a HUVEC cell line after 20 minutes at a shear rate of $200 \mathrm{~s}^{-1}$ compared to static conditions. The larger fold decrease found by Shenkman et al. may be due to strain-specific differences in adhesion. The same group found no change in S. aureus RN6390 adhesion to endothelium after 20 minutes at a shear rate of $200 \mathrm{~s}^{-1}$ compared to static [22]; indicating a dependence on strain of S. aureus. Further, Reddy and Ross found no adhesion for S. aureus 8325-4 to Bovine Aortic Endothelial Cells for any shear rate $\left(1 \mathrm{~s}^{-1}-200 \mathrm{~s}^{-1}\right)$ [21]; indicating a possible dependence on type and species of endothelial cell. However, there may be other factors contributing to the different results seen by Shenkman et al. and Reddy and Ross [23,21]. The growth phase for maximal adherence is strain specific [47]. Reddy and Ross used bacteria in the early exponential phase while Shenkman et 


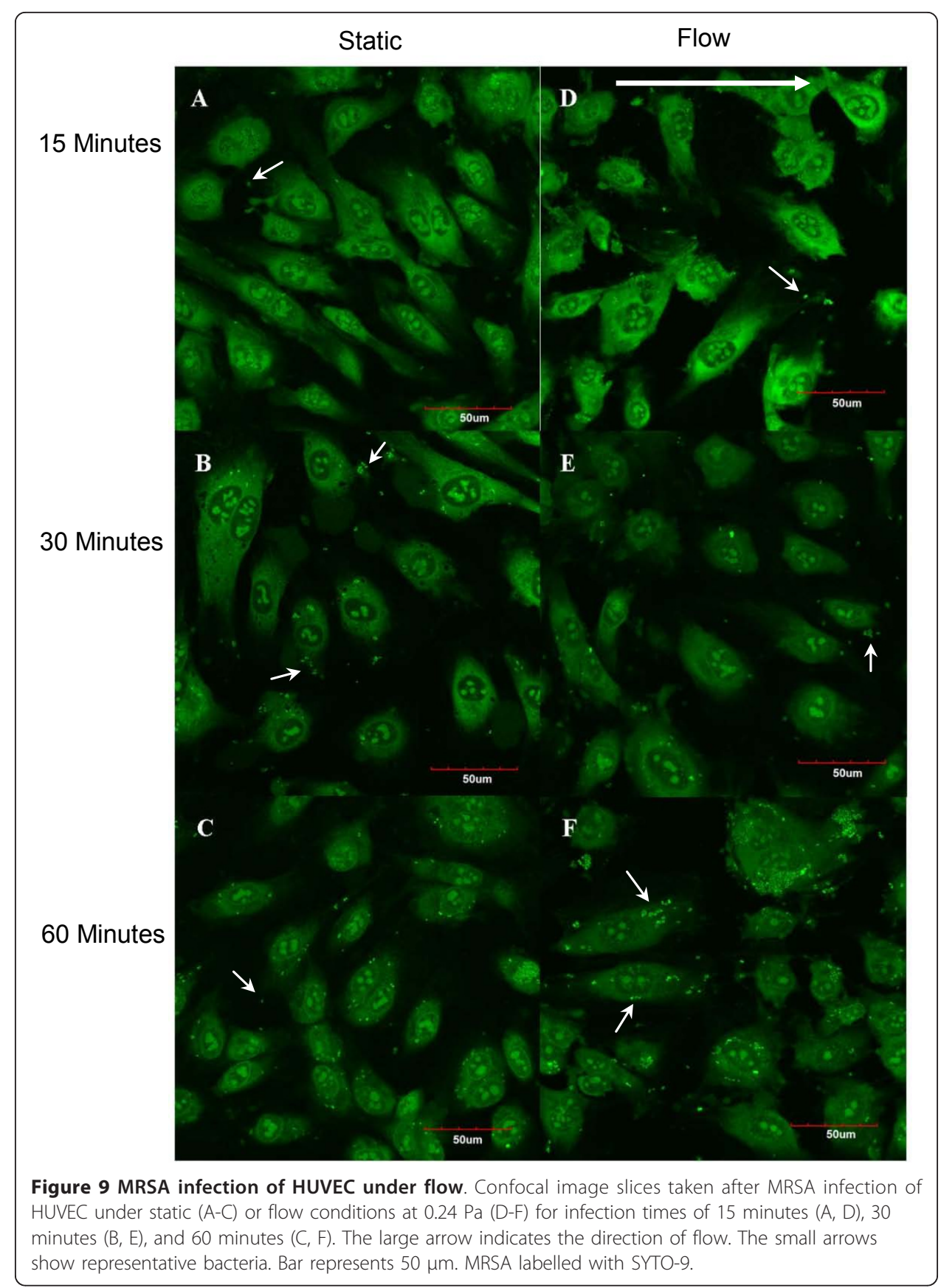

al. used bacteria in the stationary phase. At later growth phases, $S$. aureus may increase levels of an adhesin important for adhesion under flow. Further, Reddy and Ross counted surface bound bacteria, whereas Shenkman et al. measured radioactivity and thus intracellular as well as attached bacteria. In our work, we analyzed stacks obtained from confocal microscopy to quantify intracellular and extracellular bacteria, which may explain why our results agree more closely with Shenkman et al. [23].

When our results are corrected for differences in cell flux to the endothelial surface under flow, bacteria per area was shown to increase with low levels of shear $\left(293 \mathrm{~s}^{-1}\right.$; $0.24 \mathrm{~Pa})$, then decrease at the higher shear condition $\left(1460 \mathrm{~s}^{-1} ; 1.2 \mathrm{~Pa}\right)$. Lower levels of 


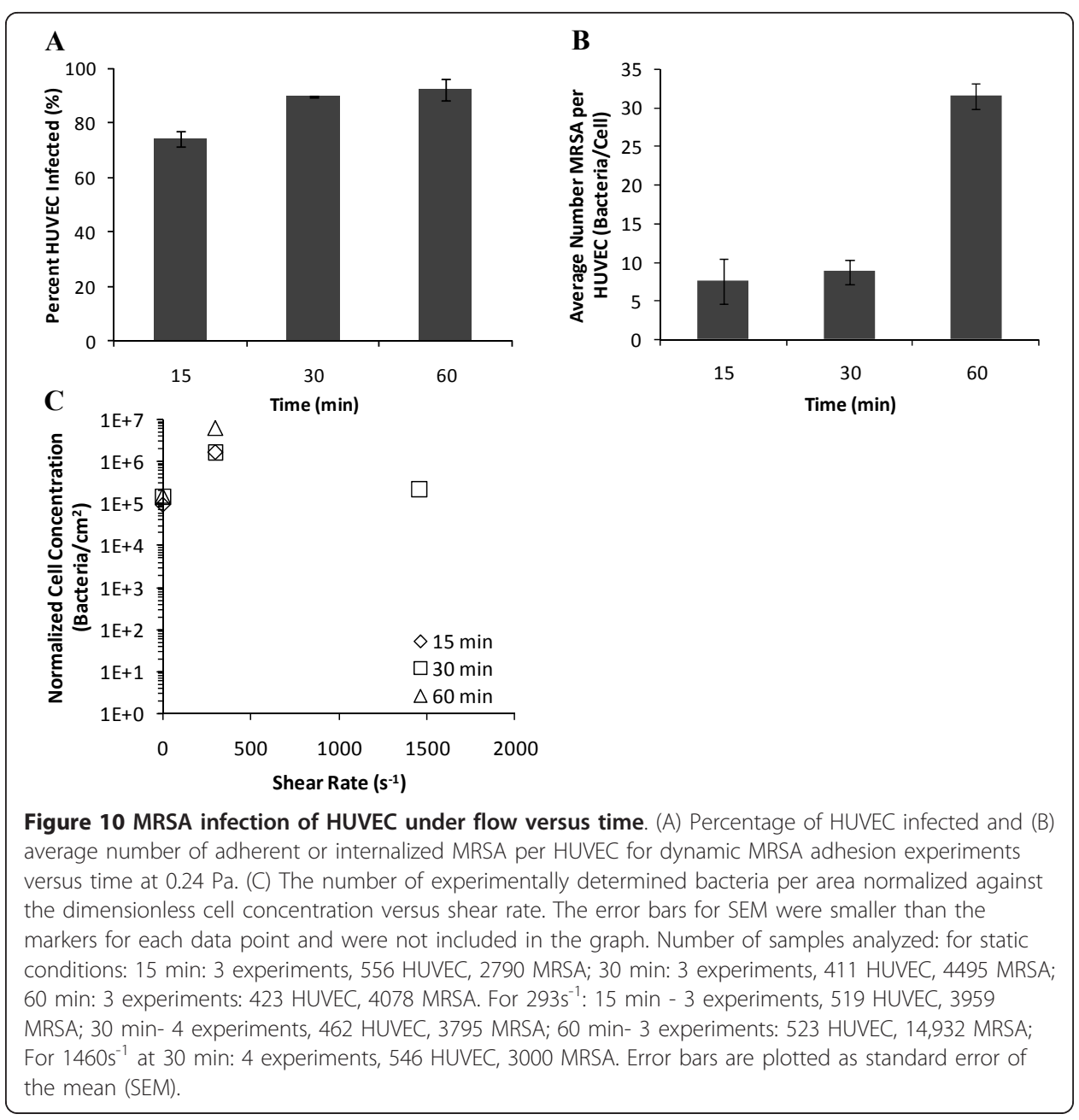

adhesion may be observed at high shear rates because adhesin-receptor bonds are less likely to form at the shortened contact times [15]. A similar trend was seen by Boks et al (2008) for Staphylococcus epidermidis on glass [50]. An analysis of the drag forces on the attached bacteria shows values of $1.9 \mathrm{pN}$ to $9.6 \mathrm{pN}$ for the conditions of this study. This force was calculated for a bacterium attached to the highest point on the endothelial cell and therefore represents a maximum. Lower forces would be present in the valleys between the cells as discussed previously. The force required to detach $S$. aureus from a collagen coated surface was found by others to be much greater than $3.9 \mathrm{pN}$ and on a fibronectin coated surface to be between 15-26 pN [51,52]. Therefore significant cell detachment may not be occurring under the conditions of this study. Catch bonds, which increase in strength with increasing shear stress, could be forming more frequently at the lower shear stress condition $(0.24 \mathrm{~Pa})$ leading to increased cell adhesion under these conditions [53,54].

MRSA exposure time affected the extent of infection under both static and flow conditions. For static experiments, endothelial binding sites may have been saturated, as there was no increase in the number of MRSA per HUVEC between 30 minutes and 60 minutes, and no significant change in the percent HUVEC infected was observed over the time course. This agrees with findings of Tompkins et al. [48] who saw 
saturation within 60 minutes for static adhesion using similar bacterial inoculum sizes. Under flow at $293 \mathrm{~s}^{-1}$, a very different result was found. There was no change in the number of MRSA per HUVEC between 15 and 30 minutes, but there was a $260 \%$ increase between 30 and 60 minutes. The presence of flow appears to be exacerbating the endothelial response to infection at the one hour time point, perhaps leading to modulation of surface properties that increase bacterial uptake. Further studies are needed to investigate the mechanisms involved.

\section{Conclusions}

This study demonstrated that MRSA adheres to endothelium in a shear dependent manner which may be affected by the non-uniform shear stress distribution over an undulating endothelial monolayer. MRSA adhered to and invaded HUVEC, with a large degree of heterogeneity. The time course of adhesion under flow conditions varied greatly as compared to static. Therefore, the mechanisms of adhesion under flow may differ from those seen under static conditions and thus warrant further investigation. During establishment of blood borne infections, bacteria contact endothelial cells throughout the vasculature. Our results suggest that at increasing time points, MRSA will adhere in increasing numbers under low flow, an effect not seen in static culture. Further, adhesion appears to be dependent on shear stress magnitude. The number of MRSA increased between the static and low flow conditions. A further increase in shear stress led to a decrease in MRSA numbers. Therefore, MRSA appear to adhere and invade endothelial cells preferentially in regions of low shear stress, such as those found in vascular branches and areas of curvature. Taken together, these findings suggest that shear stress and time each influence MRSA adhesion to, and internalization by, endothelial cells. While steady flow was assessed in this work, further studies investigating the role of flow pulsatility and recirculation should provide further insights into the role of fluid dynamics on bacterial adhesion in the vasculature.

\section{Acknowledgements}

The authors would like to thank Dr. Howard Ceri (University of Calgary) for the culture of MRSA UC18, Dr. Elena Di Martino (University of Calgary) for assisting with the statistical analysis, and Carol Chan for measurement of fluid properties. K. Viegas and M. Salek would like to acknowledge the National Science and Engineering Research Council of Canada (NSERC) and Alberta Ingenuity Fund (now part of Alberta Innovates Technology Futures), respectively, for postgraduate scholarships. K. Rinker and R. Martinuzzi would like to acknowledge support through their NSERC Discovery grants.

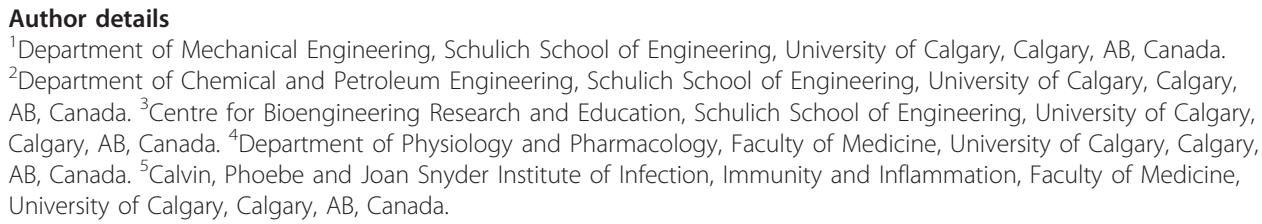




\section{References}

1. Habash M, Reid G: Microbial biofilms: their development and significance for medical device-related infections. $J$ Clin Pharmacol 1999, 39:887-899.

2. Lowy FD: Stapylococcus aureus infections. New Eng J Med 1998, 339:520-535.

3. Ross R: The pathogenesis of atherosclerosis: a perspective for the 1990s. Nature 1993, 362:801-809.

4. Beachey EH: Bacterial adherence: adhesion-receptor interactions mediating the attachment of bacterial to mucosal surfaces. J Infect Dis 1981, 143:325-345.

5. Sinha B, Herrmann M: Mechanism and consequences of invasion of endothelial cells by Staphylococcus aureus. Thromb Haemostas 2005, 94:266-277.

6. Fowler VG, Miro JM, Hoen B, et al: Staphylococcus aureus endocarditis: a consequence of medical progress. JAMA 2005, 293:3012-3021.

7. Cabell CH, Jollis JG, Peterson GE, Corey GR, Anderson DJ, Sexton DJ, Woods CW, Reller LB, Ryan T, Fowler VG: Changing patient characteristics and the effect on mortality in endocarditis. Arch Intern Med 2002, 162:90-94.

8. Grundmann H, Aires-de-Sousa M, Boyce J, Tiemersma E: Emergence and resurgence of methicillin-resistant Staphylococcus aureus as a public health threat. Lancet 2006, 368:874-885.

9. Klevins RM, Morrison MA, Nadle J, Petit S, Gershman K, Ray S, Harrison LH, Lynfield R, Dumyati G, Townes JM, Craig AS, Zell ER, Fosheim GE, McDougal LK, Carey RB, Fridkin SK: Invasive Methicillin-Resistant Staphylococcus aureus Infections in the United States. JAMA 2007, 298:1763-1771.

10. Klevins RM, Edwards JR, Tenover FC, McDonald LC, Horan T, Gaynes R: Changes in the epidemiology of methicillinresistant Staphylococcus aureus in intensive care units in US hospitals, 1992-2003. Clin Infect Dis 2006, 42:389-391.

11. Stern DM: Endothelial Cells in Physiology and in the Pathophysiology of Vascular Disorders. Blood 1998, 91:3527-3561.

12. Malek AM, Alper SL, Izumo S: Hemodynamic shear stress and its role in atherosclerosis. JAMA 1999, 282:2035-2042.

13. Reneman RS, Theo Arts Arnold P.G Hoeks: Wall Shear Stress - an Important Determinant of Endothelial Cell Function and Structure - in the Arterial System in vivo Discrepancies with Theory. J Vasc Res 2006, 43:251-269.

14. Baddour LM, Bettmann MA, Bolger AF, Epstein AE, Ferrieri P, Gerber MA, Gewitz MH, Jacobs AK, Levison ME, Newburger JW, Pallasch TJ, Wilson WR, Baltimore RS, Falace DA, Shulman ST, Tani LY, Taubert KA: Nonvalvular Cardiovascular Device-Related Infections. Circulation 2003, 108:2015-2031.

15. Rinker KD, Prabhakar $\mathrm{V}$, Truskey GA: Effect of contact time and force on monocyte adhesion to vascular endothelium. Biophys J 2001, 30:1722-1732.

16. Rinker KD, Kirkpatrick AP, Ting-Beall HP, Shepherd RD, Levin JD, Irick J, Thomas JL, Truskey GA: Linoleic acid increases monocyte deformation and adhesion to endothelium. Atherosclerosis 2004, 177:275-285

17. Lawrence MB, Kansas GS, Kunkel EJ, Ley K: Threshold levels of fluid shear promote leukocyte adhesion through selectins (CD62L,P,E). J Cell Biol 1997, 136:717-727.

18. Marshall BT, Long M, Piper JW, Yago T, McEver RP, Zhu C: Direct observation of catch bonds involving cell-adhesion molecules. Nature 2003, 423:190-193.

19. Thomas W, Forero M, Yakovenko O, Nilsson L, Vicini P, Sokurenko E, Vogel V: Catch-Bond Model Derived from Allostery Explains Force-Activated Bacterial Adhesion. Biophys J 2006, 90:753-764.

20. Yakovenko O, Sharma S, Forero M, Tchesnokova V, Aprikian P, Kidd B, Mach A, Vogel V, Sokurenko E, Thomas WE: FimH Forms Catch Bonds That Are Enhanced by Mechanical Force Due to Allosteric Regulation. J Biol Chem 2008, 283:11596-11605.

21. Reddy K, Ross JM: Shear stress prevents fibronectin binding protein-mediated Staphylococcus aureus adhesion to resting endothelial cells. Infect Immun 2001, 69:3472-3475.

22. Shenkman B, Rubinstein E, Cheung AL, Brill GE, Dardik R, Tamarin I, Savion N, Varon D: Adherence properties of Staphylococcus aureus under static and flow conditions: roles of agr and sar loci, platelets, and plasma ligands. Infect Immun 2001, 69:4473-4478.

23. Shenkman B, Varon D, Tamarin I, Dardik R, Peisachov M, Savion N, Rubinstein E: Role of agr (RNAllI) in Staphylococcus aureus adherence to fibrinogen, fibronectin, platelets and endothelial cells under static and flow conditions. $J$ Med Microbiol 2002, 51:747-754

24. Dardik A, Chen L, Frattini J, Asada H, Aziz F, Kudo FA, Sumpio BE: Differential Effects of Orbital and Laminar Shear Stress on Endothelial Cells. J Vasc Surg 2005, 41:869-880

25. Dewey CF, Bussolari SR, Gimbrone MA, Davies PF: The dynamic response of vascular endothelial cells to fluid shear stress. J Biomech Eng 1981, 103:177-185

26. Blackman BR, Garcia-Cardena G, Gimbrone MA: A new in vitro model to evaluate differential responses of endothelial cells to simulated arterial shear stress waveforms. J Biomech Eng 2002, 124:397-407.

27. Levesque MJ, Nerem RM: The elongation and orientation of cultured endothelial cells in response to shear stress. $J$ Biomech Eng 1985, 4:341-348.

28. Ruel J, Lemay J, Dumas G, Doillon C, Charara J: Development of a parallel plate flow chamber for studying cell behavior under pulsatile flow. Am Society Artif Intern Organs J 1995, 41:876-883.

29. Lawrence MB, McIntire LV, Eskin SG: Effect of flow on polymorphonuclear leukocyte/endothelial cell adhesion. Blood 1987, 70:1284-1290.

30. Shepherd RD, Kos SM, Rinker KD: Long-term pulsatile shear stress leads to increased phosphorylation of multiple MAPK species in cultured human aortic endothelial cells. Biorheology 2009, 46:529-538.

31. Yee A, Sakurai $Y$, Eskin SG, Mclntire LV: A validated system for simulating common carotid arterial flow in vitro: alteration of endothelial cell response. Ann Biomed Eng 2006, 34:593-604.

32. Bakker DP, van der Plaats A, Verkerke GJ, Busscher HJ, van der Mei HC: Comparison of velocity profiles for different flow chamber designs used in studies of microbial adhesion to surfaces. Appl Environ Microbiol 2003, 69:6280-6287.

33. Anderson EJ, Falls TD, Sorkin AM, Tate MLK: The imperative for controlled mechanical stresses in unraveling cellular mechanisms of mechanotransduction. Biomed Eng Online 2006, 5:1-14.

34. McCann JA, Peterson SD, Plesniak MW, Webster TJ, Haberstroh KM: Non-Uniform Flow Behavior in a Parallel Plate Flow Chamber Alters Endothelial Cell Responses. Ann Biomed Eng 2005, 33:328-336. 
35. Beekhuizen H, van de Gevel JS, Olsson B, van Benten IJ, van Furth R: Infection of human vascular endothelial cells with Staphylococcus aureus induces hyperadhesiveness for human monocytes and granulocytes. J Immunol 1997, 158:774-782.

36. Edgell CJS, MCDonald CC, Graham JB: Permanent cell line expressing human factor VIII-related antigen established by hybridization. Proc Natl Acad Sci USA 1983, 80:3734-3737.

37. Edwards AM, Potts JR, Josefsson E, Massey RC: Staphylococcus aureus host cell invasion and virulence in sepsis is facilitated by the multiple repeats within FnBPA. PLoS Pathogens 2010, 6:1-16.

38. Dol SS, Salek MM, Viegas KD, Rinker KD, Martinuzzi RJ: Micro-PIV and CFD studies show non-uniform wall shear stress distributions over endothelial cells. Proceedings of the ASME 2010 3rd Joint US-European Fluids Engineering Summer Meeting and 8th International Conference on Nanochannels, Microchannels and MiniChannels 2010, Montreal, Canada. Paper: FEDSM-ICNMM2010-30605.

39. Barber KM, Pinero A, Truskey GA: Effects of recirculating flow on U-937 cell adhesion to human umbilical vein endothelial cells. Am J Physiol Heart Circ Physiol 1998, 44:H591-H599.

40. Munn LL, Melder RJ, Jain RK: Analysis of cell flux in the parallel plate flow chamber: implications for cell capture studies. Biophys J 1994, 67:889-895.

41. Mohamed N, Rainier TR Jr, Ross JM: Novel experimental study of receptor-mediated bacterial adhesion under the influence of fluid shear. Biotechnol Bioeng 2000, 68:628-636.

42. Huff E, Oxley H, Silverman CS: Density-gradient patterns of Staphylococcus aureus cells and cell walls during growth and mechanical disruption. J Bacteriol 1964, 88:1155-1162.

43. Dickenson RB, Cooper ST: Analysis of shear-dependent bacterial adhesion kinetics to biomaterial surfaces. AlChE J $1995,41: 2160-2174$

44. Goldman AJ, Cox RG, Brenner H: Slow viscous motion of a sphere parallel to a plane wall-II Couette flow. Chem Eng Science 1967, 22:653-660.

45. Meinhart CD, Wereley ST, Gray MHB: Volume illumination for two-dimensional particle image velocimetry. Meas Sci Technol 2000, 11:809-814

46. Pohlmann-Dietze P, Ulrich M, Kiser KB, Doring G, Lee JC, Fournier JM, Botzenhart K, Wolz C: Adherence of Staphylococcus aureus to endothelial cells: influence of capsular polysaccharide, global regulator agr, and bacterial growth phase. Infect Immun 2000, 68:4865-4871.

47. Van Wamel WJB, Vandenbroucke-Grauls CMJE, Verhoef J, Fluit AC: The effect of culture conditions on the in-vitro adherence of methicillin-resistant Staphylococcus aureus. J Med Microbiol 1998, 47:705-709.

48. Tompkins DC, Hatcher VB, Patel D, Orr GA, Higgins LL, Lowy FD: A human endothelial cell membrane protein that binds Staphylococcus aureus in vitro. J Clin Invest 1990, 85:1248-1254.

49. Becker RC, DiBello PM, Lucas FV: Bacterial tissue tropism: an in vitro model for infective endocarditis. Cardiovascular Research 1987, 21:813-820.

50. Boks NP, Norde W, van der Mei HC, Busscher HJ: Forces involved in bacterial adhesion to hydrophilic and hydrophobic surfaces. Microbiology 2008, 154:3122-3133.

51. Mohamed N, Teeters MA, Patti JM, Hook M, Ross JM: Inhibition of Staphylococcus aureus adherence to collagen under dynamic conditions. Infect Immun 1999, 67:589-594.

52. Simpson KH, Bowden AG, Peacock SJ, Arya M, Hook M, Anvari B: Adherence of Staphylococcus aureus fibrinectin binding protein A mutants: an investigation using optical tweezers. Biomol Eng 2004, 21:105-111.

53. Thomas WE, Trintchina E, Forero M, Vogel V, Sokurenko EV: Bacterial adhesion to target cells enhanced by shear force. Cell 2002, 109:913-923.

54. Thomas W, Forero M, Yakovenko O, Nilsson L, Vicini P, Sokurenko E, Vogel V: Catch-bond model derived from allostery explains force-activated bacterial adhesion. Biophys J 2006, 90:753-764.

doi:10.1186/1475-925X-10-20

Cite this article as: Viegas et al: Methicillin resistant Staphylococcus aureus adhesion to human umbilical vein endothelial cells demonstrates wall shear stress dependent behaviour. BioMedical Engineering OnLine 2011 10:20.

\section{Submit your next manuscript to BioMed Central and take full advantage of:}

- Convenient online submission

- Thorough peer review

- No space constraints or color figure charges

- Immediate publication on acceptance

- Inclusion in PubMed, CAS, Scopus and Google Scholar

- Research which is freely available for redistribution 